\title{
PELAKSANAAN UUD 1945 (REFORMASI) DALAM PERSPEKTIF KETATANEGARAAN
}

\author{
RISKI PUTRA UTAMA HI \\ Email: Riski putrautama09@gmail.com \\ No BP: 1910003600144 \\ UNIVERSITAS EKASAKTI
}

\section{A. Pendahuluan}

Undang-Undang Dasar 1945 merupakan keseluruhan naskah yang terdiri dari Pembukaan dan Pasal-Pasal. Pembukaan dan Pasal-Pasal merupakan satu kesatuan. Di samping hukum dasar tertulis, di negara indonesia juga berlaku hukum dasar yang tidak tertulis.UUD 1945 bukan hukum biasa melainkan hukum dasar yang merupakan sumber hukum yang tertinggi, sehingga seluruh hukum yang berlaku tidak boleh bertentangan dengan UUD 1945. UUD 1945 terbentuk melalui sejarah yang amat panjang melalui pasang surutnya kejayaan bangsa dan masa-masa penderitaan penjajahan, dan masa-masa perjuangan untuk merdeka, menentukan sendiri hidup dan masa depannya.UUD 1945 untuk pertama kalinya diberlakukan pada tanggal 18 Agustus 1945, naskahnya pertama kali dimuat secara resmi dalam Berita Negara yaitu Berita Republik Indonesia Tahun II Nomor 7 tanggal 15 Februari 1946.

Berdasarkan latar belakang, Adapun Rumusan masalah yang akan di bahas dalam makalah ini yaitu Bagaimana dinamika pelaksanaan UUD 1945 pada masa reformasi. 


\section{B. Pembahasan}

\section{Dinamika Pelaksanaan UUD 1945 Pada Masa Reformasi}

Dengan berlandaskan pada Surat Perintah 11 Maret 1966, pengemban SUPERSEMAR pada tanggal 12 Maret 1966 membubarkan PKI dan ormas-ormasnya jadi dengan demikian tanggal 19 Maret 1966 dinyatakan sebagai titik awal Orde baru. Dalam masa ini telah dapat berhasil melaksanakan Undang-Undang Dasar 1945 dalam hal pembentukan lembaga-lembaga Negara dan lain-lain, namun perkembangan lebih lanjut Orde Baru didalam melaksanakan kekuasaan negara/pemerintah, sejalan dengan proses yang dihadapi ternyata terjadi penyimpanganpenyimpangan yang terlihat kepada pelaksanaan kekuasaan pemerintah mengarah otoriter. Dari pemerintah otoriter ini muncul terjadinya konflik horisontal maupun vertikal yang diakhiri oleh lengsernya Presiden Soeharto tanggal 21 Mei 1998, kemudian beralih kepada Pemerintah beraliran Reformasi.

UUD 1945 pada masa era globalisasi yang ditandai oleh reformasi berawal dari ketetapan MPR RI No. IV/MPR/1999 tentang GBHN kemudian disusul oleh Tap-Tap MPR yang lain. Dari segi pengembangan hukum terlihat pada Tap MPR No. III/MPR/2000 tentang sumber hukum dan tata urutan peraturan perundangan.

Masa Orde Baru di bawah kepemimpinan presiden Soeharto sampai tahun 1998 membuat pemerintahan Indonesia tidak mengamanatkan nilai-nilai demokrasi seperti yang tercantum dalam Pancasila, bahkan juga tidak mencerminkan pelaksanaan demokrasi atas dasar normanorma dan pasal-pasal UUD 1945. Pemerintahan dicemari korupsi, kolusi dan nepotisme (KKN). Keadaan tersebut membuat rakyat Indonesia semakin menderita. Terutama karena adanya krisis moneter yang melanda Indonesia yang membuat perekonomian Indonesia hancur. Hal itu 
menyebabkan munculnya berbagai gerakan masyarakat yang dipelopori oleh generasi muda Indonesia terutama mahasiswa sebagai gerakan moral yang menuntut adanya reformasi disegala bidang Negara.

Keberhasilan reformasi tersebut ditandai dengan turunnya presiden Soeharto dari jabatannya sebagai presiden dan diganti oleh Prof. B.J Habibie pada tanggal 21 mei 1998. Kemudian bangsa Indonesia menyadari bahwa UUD 1945 yang berlaku pada zaman orde baru masih memiliki banyak kekurangan, sehingga perlu diadakan amandemen lagi.

Berbagai macam produk peraturan perundang-undangan yang dihasilkan dalam reformasi hukum antara lain UU. Politik Tahun 1999, yaitu UU. No.2 tahun 1999, tentang partai politik, UU. No.3 tahun 1999, tentang pemilihan umum dan UU. No. 4 tahun 1999 tentang susunan dan kedudukan MPR, DPR, dan DPRD; UU otonomi daerah, yaitu meliputi UU. No.25 tahun 1999. Tentang pemerintahan daerah, UU. No.25 tahun 1999, tentang pertimbangan keuangan antar pemerintahan pusat dan daerah dan UU. No.28 tahun 1999 tentang penyelenggaraan Negara yang bersih dan bebas dari KKN. Berdasarkan reformasi tersebut bangsa Indonesia sudah mampu melaksanakan pemilu pada tahun 1999 dan menghasilkan MPR, DPR dan DPRD hasil aspirasi rakyat secara demokratis.

Sejak adanya perubahan / amandemen UUD 1945 yang pertama tersirat materi muatan konstitusi hanya diatur dalam UUD 1945 kemudian amandemen tersebut sampai perubahan keempat, secara lengkap proses amandemen pasal-pasal dimaksud dapat diperhatikan pada lampiran. Didalam era reformasi ini Pancasila tetap dipertahankan sebagai Dasar Negara dan Pancasila sebagai idiologi nasional yang merupakan cita-cita dari tujuan negara.

Didalam pengembangan lebih lanjut bahwa Pancasila sebagai paradigma yaitu merupakan pola pikir atau kerangka berpikir, disini menunjukkan bahwa pembukaan UUD 1945 
memiliki peranan penting yang menjadi satu kesatuan bersama UUD 1945. Menyangkut perubahan/amandemen UUD 1945 dimaksud diantaranya adalah untuk menghadapi perkembangan yang begitu cepat terjadi didunia.

Adapun kelebihan dan kekurangan pada masa reformasi, yaitu :

1) Kelebihan - Kelebihan pada Masa Reformasi

a) Munculnya kesadaran masyarakat akan pentingnya reformasi bagi bangsa Indonesia.

b) Kebebasan berpendapat kembali ditegakkan.

c) Pengurangan masalah Dwi Fungsi ABRI dalam pemerintahan.

d) Melakukan reformasi hukum dan perundang-undangan di Indonesia.

e) Adanya jaminan terhadap Hak Asasi Manusia.

f) Sector social politik Indonesia menjadi terbuka.

g) Pemilu yang tadinya hanya dapat diikuti oleh 3 parpol saja sekarang dapat diikuti oleh 48 parpol melalui seleksi.

h) Kekakuan hukum masa Orde Baru menjadi terpecah atau mulai lenyap.

i) Pemerintah memikirkan masalah social yang dialami masyarakat dengan mewujudkan program membentuk lapangan pekerjaan bagi pengangguaran.

j) Corak karya sastra menjadi lebih berwarna dan banyak jenisnya sesuai dengan kondisi social-politik saat itu.

k) Pemublikasian karya sastra menjadi lebih mudah dan terbantu karena adanya media komunikasi. 
1) Kekurangan - Kekurangan pada Masa Reformasi

a) Adanya perpecahan presepsi antara mahasiswa dan kelompok masyarakat mengenai pengangkatan B.J Habibie sebagai Presiden.

b) Tidak adanya pemberian subsidi terhadap masyarakat.

c) Keputusan reformasi ekonomi yang dibutuhkan tidak sesuai dengan apa yang diinginkan masyarakat.

d) Terlalu dibebani oleh program penyesuaian struktural dari IMF.

d) Posisi militer tidak mendapat tempat yang cukup baik dihati masyarakat.

e) Penanganan masalah ekonomi dan social menjadi tidak optimal karena konflik politik internal dalam negeri.

f) Adanya krisis multidimensi yang dihadapi oleh Indonesia.

g) Pemerintah hanya terfokus pada perbaikan ekonomi.

h) Kurangnya minat para pembaca pada karya sastra angkatan reformasi. 


\section{Penutup}

Pelaksanaan dinamika UUD 1945 pada orde reformasi masih banyak penyimpangan yang terjadi karena pada masa ini belum semua UUD 1945 dilaksanakan dan masih adanya korupsi, kolusi dan nepotisme. Sehingga memunculkan orde ini terjadi krisis ekonomi, krisis social, krisis politik dan krisis hukum.

\section{Daftar Pustaka}

Andrew Shandy Utama, Independensi Pengawasan Terhadap Bank Badan Usaha Milik Negara (Bumn) Dalam Sistem Hukum Nasional Di Indonesia, Soumatera Law Review, Volume 1, Nomor 1, 2018, 10.22216/soumlaw.v1i1.3312.

Annisa Arifka, Sanksi Administrasi Bagi Wajib Pajak Pajak Penghasilan Orang Pribadi Di Kota Padang, Soumatera Law Review, Volume 1, Nomor 2, 2018, 10.22216/soumlaw.v1i2.3745.

Ade Sarmini, Kualitas Pelayanan Surat Izin Mengemudi (SIM) Pada Kantor Satuan Lalu Lintas Polres Karimun, Soumatera Law Review, Volume 2, Nomor 2, 2019, 10.22216/soumlaw.v2i2.4231.

Bram Mohammad Yasser, Pengujian Unsur Penyalahgunaan Wewenang Pada Peradilan Tata Usaha Negara Dalam Kaitannya Dengan Tindak Pidana Korupsi, Soumatera Law Review, Volume 2, Nomor 1, 2019, 10.22216/soumlaw.v2i1.3558.

Danel Aditia Situngkir, Asas Legalitas Dalam Hukum Pidana Nasional Dan Hukum Pidana Internasional, Soumatera Law Review, Volume 1, Nomor 1, 2018, 10.22216/soumlaw.v1i1.3398.

Darmini Roza, Laurensius Arliman S, Peran Pemerintah Daerah Di Dalam Melindungi Hak Anak Di Indonesia, Masalah-Masalah Hukum, Volume 47, Nomor 1, 2018. https://doi.org/10.14710/mmh.47.1.2018.10-21.

Darmini Roza, Laurensius Arliman S, Peran Pemerintah Daerah untuk Mewujudkan Kota Layak Anak di Indonesia, Ius Quia Iustum Law Journal, Volume 25, Nomor 1, 2018, https://doi.org/10.20885/iustum.vol25.iss1.art10.

Darmini Roza, Laurensius Arliman S, Peran Badan Permusyawaratan Desa di Dalam Pembangunan Desa dan Pengawasan Keuangan Desa, Padjadjaran Journal of Law, Volume 4, Nomor 3, 2017. https://doi.org/10.15408/jch.v4i2.3433.

Debora Angelia Pardosi, Peran Jabatan Fungsional Auditor Terhadap Peningkatan Kinerja Birokrat Di Lingkungan Inspektorat Provinsi Jawa Tengah, Soumatera Law Review, Volume 1, Nomor 2, 2018, 10.22216/soumlaw.v1i2.3718.

Dewi Fiska Simbolon, Kurangnya Pendidikan Reproduksi Dini Menjadi Faktor Penyebab Terjadinya Pelecehan Seksual Antar Anak, Soumatera Law Review, Voume 1, Nomor 1, 2017, http://doi.org/10.22216/soumlaw.v1i1.3310.

Dian Bakti Setiawan, Keberadaan Dan Penerapan Peraturan Daerah Syari'ah Sebagai Perundang-Undangan Pada Tingkat Daerah, Soumatera Law Review, Volume 1, Nomor 1, 2018, 10.22216/soumlaw.v1i1.3327. 
Dila Andika Azhar, Analisis Yuridis Terhadap Penyimpanan Sertifikat Hak Atas Tanah Oleh Notaris Pada Proses Pengikatan Jual Beli (Pjb) (Analisis Putusan Nomor 53/Pid.B/2017/Pn.Bkt), Soumatera Law Review, Volume 2, Nomor 1, 2019, 10.22216/soumlaw.v2i1.3557.

Dola Riza, Hakikat KTUN Menurut Undang-undang Peradilan Tata Usaha Negara Vs Undangundang Admnistrasi Pemerintahan, Soumatera Law Review, Volume 2, Nomor 2, 2019, 10.22216/soumlaw.v2i2.3566.

Fadlan, Perkembangan Kebijakan Daerah Sebagai Paradigma Dasar Untuk Penentuan Kebijakan Mengelola Potensi Keberagaman, Soumatera Law Review, Volume 2, Nomor 1, 2019, 10.22216/soumlaw.v2i1.3347.

Ferdian, Lelang Terhadap Objek Jaminan Fidusia Yang Dirampas Oleh Negara Berdasarkan Putusan Pengadilan Negeri Di Kantor Pelayanan Kekayaan Negara Dan Lelang Padang, Soumatera Law Review, Volume 2, Nomor 1, 2019, 10.22216/soumlaw.v2i1.3564.

Hasnati, Tanggung Jawab Direksi Terhadap Terjadinya Kredit Macet Pada Perbankan Berdasarkan Undang-Undang Nomor 40 Tahun 2007, Soumatera Law Review, Volume 2, Nomor 1, 2019, 10.22216/soumlaw.v2i1.3319.

Hendra Sudrajat, Beggy Tamara, Peran Naskah Akademik Dan Daftar Inventarisasi Masalah Dalam Mewujudkan Peraturan Daerah Nomor 2 Tahun 2015 Tentang Perlindungan Anak Yang Aspiratif Di Kota Tangerang, Soumatera Law Review, Volume 1, Nomor 2, 2018, 10.22216/soumlaw.v1i2.3713.

Idham, Pendaftaran Tanah Dan Penerbitan Sertipikat Dalam Perspektif Free Trade Zone (FTZ) Di Kampung Tua, Kota Batam, Provinsi Kepulauan Riau, Soumatera Law Review, Volume 2, Nomor 1, 2019, 10.22216/soumlaw.v2i1.3908.

Jasmir, Pengembalian Status Hukum Tanah Ulayat Atas Hak Guna Usaha, Soumatera Law Review, Volume 1, Nomor 1, 2018, 10.22216/soumlaw.v1i1.3384.

Laurensius Arliman S, Lembaga-Lembaga Negara (Di Dalam Undang-Undang Dasar Negara Republik Indonesia Tahun 1945), Deepublish, Yogyakarta, 2016.

Laurensius Arliman S, Perlindungan Anak (Dari Undang-Undang Perlindungan Anak, UndangUndang Sistem Peradilan Pidana Anak, Wacana Kebiri Dan Bahaya LGBT Bagi Regenarasi Bangsa), Deepublish, Yogyakarta, 2016.

Laurensius Arliman S, Gokma Toni Parlindunga S, Politik Hukum Perlindungan Anak, Deepublish, Yogyakarta, 2017.

Laurensius Arliman S, Kedudukan KPAI dalam Struktur Ketatanegaraan Republik Indonesia, Deepublish, Yogyakarta, 2019.

Laurensius Arliman S, Pendidikan Kewarganegaraan - Tantangan Warga Negara Milineal Menghadapi Revolusi Industri 4.0, Yogyakarta, 2019.

Laurensius Arliman S, Protection of Girls from the Dangers of Sexual Violence in Indonesia to Design Suistanable Child Protection, Proceedings 1st Bicoshs (Prophetic Role of Sharia Knowledge in Developing Social Justice), 2017.

Laurensius Arliman S, Debora Angelina Carissa Pardosi, Peran Badan Pengawas Pemilu untuk Mengisi Kekosongan Hukum Eksploitasi Anak dalam Pelaksanaan Kampanye, Seminar Nasional Hukum Universitas Negeri Semarang, Volume 4, Nomor 2, 2018, https://doi.org/10.15294/snh.v4i02.25600.

Laurensius Arliman S, Danel Situngkir, Rianda Putri, Rahmat Fauzi, Hariyadi, Gokma Toni Parlindungan S, Cyber Bullying Against Children In Indonesia, International Conference 
on Social Sciences, Humanities, Economics and Law; Padang, 2018. DOI:10.4108/eai.59-2018.2281372.

Laurensius Arliman S, Penelantaran Perlindungan Anak Oleh Orangtua Akibat Gaya Hidup Modernisasi Yang Salah Arah, Konferensi Nasional Sosiologi V, Asosiasi Program Studi Sosiologi Indonesia, Volume 5, Padang 18-19 Mei 2017.

Laurensius Arliman S, Penegakan Hukum Bisnis Ditinjau Dari Undang-Undang Larangan Praktek Monopoli Dan Persaingan Usaha Tidak Sehat, Lex Jurnalica, Volume 16, Nomor 3, 2019.

Laurensius Arliman S, Analisis Dari Perspektif Politik Hukum Terhadap Pasal 56 UndangUndang Nomor 8 Tahun 1981 Tentang Kitab Undang Undang Hukum Acara Pidana, Lex Jurnalica, Volume 15, Nomor 3, 2018.

Laurensius Arliman S, Perlindungan Hukum Terhadap Karya Desain Industri Di Indonesia, Lex Jurnalica, Volume 15, Nomor 2, 2018.

Laurensius Arliman S, Perlindungan Hak Anak Di Dalam Memperoleh Pelayanan Kesehatan Di Indonesia, Lex Jurnalica, Volume 15, Nomor 1, 2018.

Laurensius Arliman S, Perlindungan Hak Anak Yang Berhadap Dengan Hukum Di Wilayah Hukum Polisi Resort Kota Sawahlunto, Lex Jurnalica, Volume 14, Nomor 2, 2018.

Laurensius Arliman S, Kedudukan Lembaga Perlindungan Saksi Dan Korban Terhadap Perlindungan Hak Anak Yang Bekelanjutan Di Indonesia, Lex Jurnalica, Volume 14, Nomor 1, 2018.

Laurensius Arliman S, Perlindungan Hukum UMKM Dari Eksploitasi Ekonomi Dalam Rangka Peningkatan Kesejahteraan Masyarakat, Jurnal RechtsVinding, Volume 6, Nomor 3, 2017.

Laurensius Arliman S, Partisipasi Masyarakat Di Dalam Perlindungan Anak Yang Berkelanjutan Sebagai Bentuk Kesadaran Hukum, Padjadjaran Journal of Law, Volume 3, Nomor 2, 2016. https://doi.org/10.22304/pjih.v3n2.a5.

Laurensius Arliman S, Penanaman Modal Asing Di Sumatera Barat Berdasarkan UndangUndang Nomor 25 Tahun 2007 Tentang Penanaman Modal, Supremasi Hukum, Volume 1, Nomor 1, 2018. http://dx.doi.org/10.36441/hukum.v1i01.102.

Laurensius Arliman S, Kodifikasi RUU KUHP Melemahkan Komisi Pemberantasan Korupsi, UIR Law Review, Volume 2, Nomor 1, 2018 https://doi.org/10.25299/uirlrev.2018.2.01.1437.

Laurensius Arliman S, Perlindungan Hukum Terhadap Anak Yang Tereksploitasi Secara Ekonomi Di Kota Padang, Jurnal Arena Hukum, Volume 9, Nomor 1, 2016, https://doi.org/10.21776/ub.arenahukum.2016.00901.5

Laurensius Arliman S dan Hariyadi, Peran Orangtua Dalam Mengawasi Anak Dalam Mengakses Media Internet Untuk Mewujudkan Perlindungan Hak Anak, Soumatera Law Review, Volume 1, Nomor 2, 2018, http://doi.org/10.22216/soumlaw.v1i2.3716.

Laurensius Arliman S, Peran Investasi dalam Kebijakan Pembangunan Ekonomi Bidang Pariwisata di Provinsi Sumatera Barat, Kanun Jurnal Ilmu Hukum, Volume 20, Nomor 2, 2018, https://doi.org/10.24815/kanun.v20i2.10081.

Laurensius Arliman S, Perlindungan Hukum Bagi Anak Dalam Perspektif Pancasila Dan Bela Negara, Jurnal Ilmu Hukum Unifikasi, Volume 5, Nomor 1, 2018, https://doi.org/10.25134/unifikasi.v5i1.754. 
Laurensius Arliman S, Hukum Adat Di Indonesia Dalam Pandangan Para Ahli Dan Konsep Pemberlakuannya di Indonesia, Jurnal Selat, Volume 5, Nomor 2, 2018, https://doi.org/10.31629/selat.v5i2.320.

Laurensius Arliman S, Perkembangan Dan Dinamika Hukum Ketenagakerjaan Di Indonesia, Jurnal Selat, Volume 5, Nomor 1, 2017.

Laurensius Arliman S, Peran Pemerintah Daerah Dalam Perlindungan Hak Anak Berdasarkan Undang-Undang Nomor 35 Tahun 2014 Tentang Perlindungan Anak, Jurnal Yustisia, Volume 22, Nomor 1, 2015.

Laurensius Arliman S, Eksistensi Hukum Lingkungan dalam Membangun Lingkungan Sehat Di Indonesia, Jurnal Lex Librum, Volume 5, Nomor 1, 2018, http://doi.org/10.5281/zenodo.1683714.

Laurensius Arliman S, Perlindungan Anak Oleh Masyarakat Ditinjau Dari Mazhab Sejarah Di Dalam Penerapan Prinsip The Best Interest Of The Child Pada Kehidupan Anak Di Indonesia, Era Hukum-Jurnal Ilmiah Ilmu Hukum, Volume 15, Nomor 1, 2017, http://dx.doi.org/10.24912/era\%20hukum.v15i1.668.

Laurensius Arliman S, Reformasi Penegakan Hukum Kekerasan Seksual Terhadap Anak Sebagai Bentuk Perlindungan Anak Berkelanjutan, Kanun Jurnal Ilmu Hukum, Volume 19, Nomor 2, 2017.

Laurensius Arliman S, Tinjauan Kedudukan Pengguna Anggaran Dan Kuasa Pengguna Anggaran, $\quad$ Volume $\quad 8, \quad$ Nomor $\quad 2, \quad 2015$, https://doi.org/10.21776/ub.arenahukum.2015.00802.1

Laurensius Arliman S, Penyelesaian Konflik Antar Umat Beragama (Studi Pada Komnas HAM Perwakilan Sumatera Barat), Padjadjaran Jurnal Ilmu Hukum, 2015,

Laurensius Arliman S, Imelda Tamba, Maria Florida Bunga Makin, Kualitas Pelayanan Sdm Mempengaruhi Kepuasan Anggota Koperasi Simpan Pinjam Credit Union Jembatan Kasih Kp Tanjung Uncang Di Kota Batam, Jurnal Marketing, Volume 1, Nomor 1, 2018.

Laurensius Arliman S, Fungsi Badan Kehormatan Dewan Perwakilan Rakyat Daerah Kota Padang, Jurnal Ilmiah Hukum De'Jure, Volume 1, Nomor 2, 2017.

Laurensius Arliman S, Urgensi Notaris Syari'ah Dalam Bisnis Syari'ah Di Indonesia, Walisongo: Jurnal Penelitian Sosial Keagamaan, Volume 24, Nomor 1, Mei 2016, DOI: http://dx.doi.org/10.21580/ws.2016.24.1.676.

Laurensius Arliman S, Pendidikan Paralegal Kepada Masyarakat Sebagai Bentuk Perlindungan Anak Yang Berkelanjutan, UIR Law Review, Volume 1, Nomor 1, 2017, https://doi.org/10.25299/ulr.2017.1.01.153

Laurensius Arliman S, Peran Lembaga Catatan Sipil Terhadap Perkawinan Campuran Berdasarkan Undang-Undang Perkawinan, Cendekia Hukum, Volume 4, Nomor 2, 2019, http://doi.org/10.33760/jch.v4i2.40.

Laurensius Arliman S, Partisipasi Masyarakat di Daerah Perbatasan NKRI untuk Mencegah Anak Sebagai Objek Human Trafficking, Wawasan Yuridika, Volume 2, Nomor 1, 2018, http://dx.doi.org/10.25072/jwy.v2i1.162.

Laurensius Arliman S, Memperkuat Kearifan Lokal Untuk Menangkal Intoleransi Umat Beragama Di Indonesia, Ensiklopedia of Journal, Volume 1, Nomor 1, 2018, https://doi.org/10.33559/eoj.v1i1.18.

Laurensius Arliman S, Perkawinan Antar Negara Di Indonesia Berdasarkan Hukum Perdata Internasional, Kertha Patrika, Volume 39, Nomor 3, 2017, https://doi.org/10.24843/KP.2017.v39.i03.p03. 
Laurensius Arliman S, Komisi Penyiaran Indonesia Sebagai State Auxialiary Bodies Yang Menjamin Siaran Yang Layak Bagi Anak, Veritas et Justitia, Volume 3, Nomor 1, 2017, https://doi.org/10.25123/vej.2528.

Laurensius Arliman S, Partispasi Pemerintah Daerah Di Dalam Perlindungan Anak Yang Berkelanjutan Di Indonesia, Jurnal Ilmu Hukum, Volume 7, Nomor 2, 2016.

Laurensius Arliman S, Sumbangsih Werda Notaris Dalam Organisasi Ikatan Notaris Indonesia, Jurnal Yuridika, Volume 30, Nomor 3, 2015, https://doi.org/10.20473/ydk.v30i3.1770.

Laurensius Arliman S, Peran Dewan Pers Sebagai Lembaga Negara Independen Yang Menjamin Berita Yang Layak Bagi Perlindungan Anak, Mahkamah: Jurnal Kajian Hukum Islam, Volume 4, Nomor 2, 2019, https://doi.org/10.24235/mahkamah.v4i2.4972.

Laurensius Arliman S, Menjerat Pelaku Penyuruh Pengrusakan Barang Milik Orang Lain Dengan Mempertimbangkan Asas Fungsi Sosial Kajian Putusan Nomor 267/Pid. B/2015/PN. Blg, Jurnal Gagasan Hukum, Volume 01, Nomor 1, 2019,

Laurensius Arliman S, Partisipasi Masyarakat Di Dalam Pengelolaan Uang Desa Pasca Undang-Undang Nomor 6 Tahun 2014 Tentang Desa, Jurnal Arena Hukum, Volume 12, Nomor 2, 2019, https://doi.org/10.21776/ub.arenahukum.2019.01202.5.

Laurensius Arliman S, Pelaksanaan Penyidikian Tindak Pidana Penghinaan Terhadap Agama Melalui Konten Video Melalui Media Sosial, Ensiklopedia Sosial Review, Volume 01, Nomor 1, 2019.

Laurensius Arliman S, Perlindungan Anak dalam Proses Penyidikan di Polresta Padang, Jurnal Ijtihad, Volume 31, Nomor 2, 2015, http://dx.doi.org/10.15548/ijt.v31i2.63,

Laurensius Arliman S, Yulfasni, Tanggung Jawab Perseroan Terbatas Dihubungkan dengan Good Corporate Governance dalam Rangka Mencegah Penyalahgunaan Kekuasaan Pemegang Saham, Pagaruyuang Law Journal, Volume 3, Nomor 1, 2019.

Laurensius Arliman S, Surat Dakwaan dalam Hukum Acara Pidana Sebagai Bentuk Mendukung Penegakan Hukum di Indonesia, Kosmik Hukum, Volume 19, Nomor 1, 2019, https://doi.org//10.30595/kosmikhukum.v19i1.4081.

Laurensius Arliman S, Mewujudkan Penegakan Hukum Yang Baik Di Negara Hukum Indonesia, Dialogica Jurnalica, Volume 11, Nomor 1, 2019, https://doi.org/10.28932/di.v11i1.1831.

Laurensius Arliman S, Politik Hukum Kenotariatan Pasca Perubahan Undang-Undang Jabatan Notaris Bagi Notaris Dalam Menjalankan Jabatannya, Dialogica Jurnalica, Volume 9, Nomor 2, 2018, https://doi.org/10.28932/di.v9i2.976.

Laurensius Arliman S, Mediasi Melalui Pendekatan Mufakat Sebagai Lembaga Alternatif Penyelesaian Sengketa Untuk Mendukung Pembangunan Ekonomi Nasional, UIR Law Review, Volume 2, Nomor 2, 2018, https://doi.org/10.25299/uirlrev.2018.vol2(02).1587.

Laurensius Arliman S, Jaksa Sebagai Pengacara Negara Menurut Undang-undang Kejaksaaan, Jendela Hukum dan Keadilan, Volume 5, Nomor 1, 2018.

Laurensius Arliman S, Pemakzulan Presiden Dan Wakil Presiden Di Indonesia, Justicia et Pax, Volume 34, Nomor 1, 2018, https://doi.org/10.24002/jep.v34i1.1652.

Laurensius Arliman S, Implementasi Keterbukaan Informasi Pubik Untuk Mendukung Kinerja Aparatur Sipil Negara Yang Profesional, Cendikia Hukum, Volume 3, Nomor 2, 2018, http://doi.org/10.33760/jch.v3i2.18.

Laurensius Arliman S, Peranan Pers Untuk Mewujudkan Perlindungan Anak Berkelanjutan Di Indonesia, Jurnal Ilmu Hukum Tambun Bungai, Volume 2, Nomor 2, 2017. 
Laurensius Arliman S, Kedudukan Komisi Perlindungan Anak Indonesia Sebagai State Auxiliary Bodies Dalam Sistem Hukum Ketatanegaraan Indonesia, Justitia et Pax, Volume 32, Nomor 2, 2016, https://doi.org/10.24002/jep.v32i2.1151.

Laurensius Arliman S, Pelaksanaan Penanganan Tindak Pidana Narkotika Oleh Sudbit Keamanan Dengan Subdit Narkotika Kepolisian Daerah Sumatera Barat, Journal of Islamic and Law Studies, Volume 3, Nomor 2, 2019, https://doi.org/10.18592/jils.v3i2.3237.

Laurensius Arliman S, Konsep dan Gagasan Pengenalan Pendidikan Antikorupsi Bagi Anak dalam Rangka Mewujudkan Generasi yang Bebas Korupsi, Nurani: Jurnal Kajian Syari'ah dan Masyarakat, Volume 17, Nomor 1, 2017 , https://doi.org/10.19109/nurani.v17i1.1348.

Laurensius Arliman S, Dinamika Dan Gagasan Mencegah Eksploitasi Anak Dalam Pemilihan Umum Kepala Daerah, Jurnal Jentera, Volume 1, Nomor 1, 2017.

Laurensius Arliman S, Perlindungan Terhadap Anak Sebagai Salah Satu Wujud Tujuan Bela Negara, Respublica, Volume 17, Nomor 1, 2017 , https://doi.org/10.31849/respublica.v17i1.1453.

Laurensius Arliman S, Komnas Perempuan Sebagai State Auxialiary Bodies Dalam Penegakan Ham Perempuan Indonesia, Justicia Islamica, Volume 14, Nomor 2, 2017, https://doi.org/10.21154/justicia.v14i2.1228.

Laurensius Arliman S, Hukum Pidana Sebagai Landasan Penegakan Hukum Oleh Penegak Hukum Di Indonesia, Jurnal Jendela Hukum dan Keadilan, Volume 4, Nomor 2, 2017.

Laurensius Arliman S, Politik Hukum Pembentukan Undang-Undang Perlindungan Anak Untuk Mewujudkan Perlindungan Anak Yang Berkelanjutan, Syiar Hukum, Volume 15, Nomor 2, 2017, https://doi.org/10.29313/sh.v15i2.2857.

Laurensius Arliman S, Undang-undang 17 Tahun 2016 Tentang Penetapan Perppu 1 Tahun 2016 Sebagai Wujud Perlindungan Anak Ditinjau Dari Perspektif Hukum Tata Negara, Jurnal Hukum Positum, Volume 1, Nomor 2, 2017 , http://dx.doi.org/10.35706/positum.v1i2.846.

Laurensius Arliman S, Hak Atas Pengadaan Dan Standar Rumah Bagi Mantan Presiden Dan/Atau Wakil Presiden Republik Indonesia, Jurnal Yuridis, Volume 4, Nomor 1, 2017, http://dx.doi.org/10.35586/.v4i1.131.

Laurensius Arliman S, Pengadilan Hak Asasi Manusia Dari Sudut Pandang Penyelesaian Kasus Dan Kelemahannya, Jurnal Ilmu Hukum Tambun Bungai, Volume 2, Nomor 1, 2017.

Laurensius Arliman S, Pemanggilan Notaris Dalam Rangka Penegakan Hukum Paska Perubahan Undang-Undang Jabatan Notaris, Justicia et Pax, Volume 32, Nomor 1, 2016, https://doi.org/10.24002/jep.v32i1.758.

Laurensius Arliman S, Perlindungan Hukum Terhadap Anak Yang Tereksploitasi Secara Ekonomi Di Kota Padang, Arena Hukum, Volume 9, Nomor 1, 2016, https://doi.org/10.25123/vej.2076.

Laurensius Arliman S, Tinjauan Kedudukan Pengguna Anggaran dan Kuasa Pengguna $\begin{array}{lllll}\text { Anggaran, } & \text { Volume } & \text { 8, Nomor } & 2, & \text { 2015, }\end{array}$ https://doi.org/10.21776/ub.arenahukum.2015.00802.1.

Laurensius Arliman S, Bolehkan Notaris Melakukan Penyuluhan Hukum Pasar Modal Melalui Media Internet? Jurnal Hukum dan Bisnis (Selisik), Volume 2, Nomor 1, 2016, https://doi.org/10.35814/selisik.v2i1.638. 
Laurensius Arliman S, Hak Ingkar (Verschoningsplicht) Atau Kewajiban Ingkar (Verschoning Splicht) Notaris Didalam Undang-Undang Jabatan Notaris, Doctrinal, Volume 1, Nomor $1,2016$.

Laurensius Arliman S, Peranan Filsafat Hukum Dalam Perlindungan Hak Anak Yang Berkelanjutan Sebagai Bagian Dari Hak Asasi Manusia, Doctrinal, Volume 1, Nomor 2, 2016.

Laurensius Arliman S, Partisipasi Aktif dan Pasif Publik dalam Pembentukan Peraturan Daerah di Kota Payakumbuh, Lex Librum: Jurnal Ilmu Hukum, Volume 2, Nomor 1, 2015.

Laurensius Arliman S, Wakil Menteri dalam Sistem Pemerintahan Indonesia, Jurnal Manajemen Sumber Daya Manusia, Volume 2, Nomor 2, 2015.

Laurensius Arliman S, Dispensasi Perkawinan Bagi Anak Di Bawah Umur Di Pengadilan Agama Padang Sidempuan, Jurnal Al Adalah, Volume 12, Nomor 4, 2015.

Laurensius Arliman S, Implikasi Putusan Mahkamah Konstitusi Dan Perubahan Undang Undang Jabatan Notaris Terhadap Pengawasan Notaris, Jurnal Respublica, Volume 16, Nomor 1, 2016, https://doi.org/10.31849/respublica.v16i1.1427.

Laurensius Arliman S, Wacana Program Pembangunan Nasional Semesta Berencana atau GBHN sebagai Landasan Pembangunan Negara Berkelanjutan, Jurnal Manajemen Pembangunan, Volume 3, Nomor 3, 2016.

Laurensius Arliman S, Gagalnya Perlindungan Anak Sebagai Salah Satu Bagian Dari Hak Asasi Manusia Oleh Orang Tua Ditinjau Dari Mazhab Utilitarianisme, Jurnal Yuridis, Volume 3, Nomor 2, 2016, http://dx.doi.org/10.35586/.v3i2.180.

Laurensius Arliman S, Mewujudukan Harmonisasi Lembaga Negara Independen Terhadap Konsep Perlindungan Hak Anak Yang Berkelanjutan, Jendela Hukum dan Keadilan, Volume 3, Nomor 2, 2016.

Laurensius Arliman S, Prostitusi Anak Laki-Laki Sebagai Kegagalan Perlindungan Anak, Istinbath, Volume 3, Nomor 2, 2016.

Laurensius Arliman S, Penyelenggaraan Sistem Presidensil Berdasarkan Konstitusi Yang Pernah Berlaku Di Indonesia, Jurnal Muhakamah, Volume 4, Nomor 2, 2019.

Melki, Hubungan DPRD dan Pemerintah Daerah Dalam Penetapan Anggaran Pendapatan Dan Belanja Daerah, Soumatera Law Review, Volume 1, Nomor 1, 2018, 10.22216/soumlaw.v1i1.3385.

Muhammad Afif, Penemuan Hukum Oleh Hakim Terhadap Kasus Carok Akibat Sengketa Tanah Dalam Masyarakat Madura, Soumatera Law Review, Volume 1, Nomor 2, 2018, 10.22216/soumlaw.v1i2.3714.

Miszuarty Putri, Pelaksanaan Restitusi Bagi Anak Yang Menjadi Korban Tindak Pidana Sebagai Bentuk Pembaruan Hukum Pidana Berdasarkan Peraturan Pemerintah Nomor 43 Tahun 2017, Soumatera Law Review, Volume 2, Nomor 1, 2019, 10.22216/soumlaw.v2i1.3567.

Muhamad Rasyad, Pembuatan Akta Perdamaian Dalam Penyelesaian Sengketa Tanah Ulayat Melalui Notaris Di Kabupaten Agam, Soumatera Law Review, Volume 2, Nomor 1, 2019, 10.22216/soumlaw.v2i1.3569.

Muhammad Taufiqurrahman, Peran Perancang Peraturan Perundang-Undangan Kementerian Hukum dan Hak Asasi Manusia dalam Pengawasan Produk Hukum Daerah Melalui Executive Preview, Soumatera Law Review, Volume 2, Nomor 2, 2019, 10.22216/soumlaw.v2i2.4341. 
Mardalena Hanifah, Perkawinan Beda Agama Ditinjau dari Undang-undang Nomor 1 Tahun 1974 Tentang Perkawinan, Soumatera Law Review, Volume 2, Nomor 2, 10.22216/soumlaw.v2i2.4420.

Oky Nasrul, Pemanfaatan Tanah Aset PT Kereta Api Indonesia (Persero) Divisi Regional II Sumatera Barat Oleh Pihak Ketiga, Soumatera Law Review, Volume 2, Nomor 1, 2019, 10.22216/soumlaw.v2i1.3554.

Rahmat Fauzi, Perkawinan Campuran Dan Dampak Terhadap Kewarganegaraan Dan Status Anak Menurut Undang-Undang Di Indonesia, Soumatera Law Review, Volume 1, Nomor 1, 2018, 10.22216/soumlaw.v1i1.3395.

Rahmat Fauzi, Faisal, Efektifitas Mediasi Dalam Menyelesaikan Sengketa Perceraian (Study Di Pengadilan Agama Bukittinggi Dan Pengadilan Agama Payakumbuh Tahun 2015-2017), Soumatera Law Review, Volume 1, Nomor 2, 2018, 10.22216/soumlaw.v1i2.3722.

Rahmat Riardo, Konversi Hak Atas Tanah Ulayat Kaum Menjadi Hak Milik Melalui Program Pendaftaran Tanah Sistimatis Lengkap di Kota Solok, Soumatera Law Review, Volume 2, Nomor 2, 2019, 10.22216/soumlaw.v2i2.3566.

Rianda Prima Putri, Pemeriksaan Penggabungan Gugatan Ganti Kerugian Dalam Perkara Pidana Di Pengadilan Negeri Kelas 1B Bukittinggi, Soumatera Law Review, Volume 1, Nomor 1, 2018, 10.22216/soumlaw.v1i1.3348.

Ridwan Putra, Prospek Pembentukan Daerah Istimewa Sumatera Barat Dalam Koridor Negara Kesatuan Republik Indonesia, Soumatera Law Review, Volume 1, Nomor 2, 2018, 10.22216/soumlaw.v1i2.3529.

Rustan Sinaga, Peran Pengadilan Hubungan Industrial Pada Pengadilan Negeri Padang Kelas IA Dalam Memberikan Kepastian Hukum Terhadap Perkara Pemutusan Hubungan Kerja, Soumatera Law Review, Volume 1, Nomor 2, 2018 , 10.22216/soumlaw.v1i2.3528.

Ratih Agustin Wulandari, Tata Kelola Perusahaan Oleh Direksi PT BPR Dharma Nagari Menerapakan Prinsip Good Corporate Governance, Soumatera Law Review, Volume 2, Nomor 2, 2019, 10.22216/soumlaw.v2i2.3568.

Rusmilawati Windari, Penanggulangan Eksploitasi Seksual Komersial Anak (ESKA) Berdasarkan Global - Local Based Approach (Glocalization), Soumatera Law Review, Volume 2, Nomor 2, 2019, 10.22216/soumlaw.v2i2.4369.

Sayid Anshar, Konsep Negara Hukum dalam Perspektif Hukum Islam, Soumatera Law Review, Volume 2, Nomor 2, 2019, 10.22216/soumlaw.v2i2.4136.

Sandra Dewi, Mengenal Doktrin Dan Prinsip Piercing The Corporate Veil Dalam Hukum Perusahaan, Soumatera Law Review, Volume 1, Nomor 2, 2018, 10.22216/soumlaw.v1i2.3744.

Tommy Busnarma, Penerapan Sanksi Pidana Denda Terhadap Pelaku Tindak Pidana Penyalahgunaan Dan Peredaran Gelap Narkotika Di Pengadilan Negeri Padang, Soumatera Law Review, Volume 2, Nomor 1, 2019, 10.22216/soumlaw.v2i1.3559.

Wahyudi, Tanggungjawab Hukum Apoteker dalam Pemusnahan Obat Narkotika di Rumah Sakit, Soumatera Law Review, Volume 2, Nomor 2, 10.22216/soumlaw.v2i2.4484.

Yasmirah Mandasari, Sanksi Pidana Terhadap Kandungan Non Halal Terhadap Produk Makanan Bersertifikat Halal Yang Dilakukan Korporasi, Soumatera Law Review, Volume 2, Nomor 2, 2019, 10.22216/soumlaw.v2i2.4339.

Yohanis, Perkawinan Poligami Di Wilayah Hukum Pengadilan Agama Kota Padang (Mekanisime Pemberian Izin, Dasar Hukum, Syarat-Syarat Poligami Dan 
Pelaksanaanya), Soumatera Law Review, Volume 1, Nomor 1, 2018, 10.22216/soumlaw.v1i1.3403. 